ANALYZE OF THE PROFITABILITY, LIQUIDITY AND SOLVENCY RATIOS ON CASH DIVIDENDS IN LQ45 INDEX COMPANIES LISTED ON THE INDONESIA STOCK EXCHANGE FOR

THE 2015-2019 PERIOD

\title{
PENGARUH RASIO PROFITABILITAS, LIKUIDITAS DAN SOLVABILITAS TERHADAP DIVIDEN TUNAI PADA PERUSAHAAN INDEKS LQ45 YANG TERDAFTAR DI BURSA EFEK INDONESIA TAHUN 2015-2019
}

Oleh:

Aziexho V ${ }^{1)}$ Enggar Diah P A ${ }^{2)}$ Tona Aurora L ${ }^{3)}$

${ }^{1)}$ Alumni Magister Ilmu Akuntansi Pascasarjana Universitas Jambi Tahun 2021, bekerja di BPKPD

Kabupaten Kerinci, Jambi - Indonesia

${ }^{2 \& 33)}$ Fakultas Ekonomi dan Bisnis Universitas Jambi-Indonesia

Email : vornandesaziexho@gmail.com ${ }^{1)}$,enggar_diah@unja.ac.id ${ }^{2)}$,tonalubis@unja.ac.id ${ }^{3)}$

\begin{abstract}
ABSTRACK
This study aims to analyze the effect of Profitability, Liquidity and Solvency Ratios on Cash Dividends in LQ45 Index companies listed on the Indonesia Stock Exchange for the 2015-2019 period. This sample selection used purposive sampling method. Hypothesis testing using multiple linear regression with statistical procedures using SPSS software version 23.The results showed that the Quick Ratio, Earning Per Share and Debt to Total Assets had an effect on the distribution of cash dividends. Return On Investment, Current Ratio, and firm size have no effect on the distribution of cash dividends.
\end{abstract}

Keywords: Return On Investment, Quick Ratio, Current Ratio, Earning Per Share, Debt to Total Asset, firm size and Cash Dividend

\begin{abstract}
ABSTRAK
Penelitian ini bertujuan untuk menganalisis pengaruh Rasio Profitabilitas, Likuiditas dan Solvabilitas terhadap Dividen Tunai pada perusahaan Indeks LQ45 yang terdaftar di Bursa Efek Indonesia Periode 2015-2019. Penelitian ini menggunakan metode purposive sampling. Pengujian hipotesis pada penelitian ini menggunakan regresi linear berganda dengan prosedur statistic menggunakan software SPSS versi 23. Hasil penelitian menyatakan Quick Ratio, Earning Per Share dan Debt to Total Asset memiliki pengaruh terhadap pembagian dividen tunai. Return On Investment, Current Ratio, dan firm size tidak berpengaruh terhadap pembagian dividen tunai.

Kata Kunci: Return on Investment, Quick Ratio, Current Ratio, Earning Per Share, Debt to Total Asset, Firm Size dan Dividen Tunai.
\end{abstract}




\section{PENDAHULUAN}

\subsection{Latar Belakang}

Perusahaan mengoperasikan bisnisnya baik itu perusahaan skala kecil ataupun perusahaan skala besar membutuhkan modal dalam mendukung kegiatan bisnisnya. Modal ini dapat bersumber dari internal perusahaan (berupa modal yang disetor oleh pemiliknya) dan berasal dari luar perusahaan (berupa pinjaman kepada pihak eksternal), namun perusahaan juga memerlukan modal dengan menjual saham kepada pihak luar/ masyarakat. (Amyas dkk, 2013)

Investor saat ini sebagian besar lebih tertarik menginvestasikan dananya didalam pasar modal. Pasar modal di Indonesia telah meningkat pesat dan berperan penting dalam mengumpulkan dana dari pihak luar/masyarakat yang ingin menginvestasikan dananya. Bursa Efek Indonesia adalah tempat untuk melakukan pembelian saham dan obligasi di Indonesia. (Wicaksono dkk, 2016)

Pasar modal adalah tempat penjual dan pembeli melakukan transaksi untuk membeli saham dan obligasi untuk memperoleh modal. Penjual adalah perusahaan yang menginginkan modal, penjual akan terus menjual saham dan obligasi di pasar modal. Pembeli juga disebut investor adalah pihak membeli modal di perusahaan yang menurut mereka akan memberikan keuntungan dan prospek yang bagus bagi mereka (Muljono, 2015).

Dividen menjadi hal yang menarik bagi investor untuk menanamkan modalnya diperusahaan. Perusahaan yang mempunyai akumulasi tingkat net profit (laba bersih) yang cukup baik antar periode, umumnyanya berkapasitas dalam mendistribusikan sebagian net profit (laba bersih) terhadap pemangku kepentingan dan investor atau para pemegang saham. Pemberian net profit (laba bersih) terhadap pemangku kepentingan dan investor atau para pemegang saham umumnya diberikan berupa dividen. Biasanya pembagian dividen berupa dana berbentuk tunai kas atau biasa juga berbentuk saham biasa (Hery, 2015).

Kebijakan pembagian dividen tunai pada perusahaan yang mengarah mendistribusikan dividen tunai dalam ukuran relatif tiggi tentunya mampu memberikan motivasi pihak pemangku pentingan dan pemegang saham atau investor untuk mendapatkan obligasi dan saham pada perusahaan. Bagi kreditor, pembagian dividen kas tentunya menjadikan pertanda tentang kemampuan kas di perusahaan dalam mendisteribusikan bunga atau justru memenuhi pokok pinjaman (Zuwita dan Enny, 2017).

Perusahaan berhadapan dengan banyak risiko kebijakan, diantaranya: perusahaan diharuskan menunda pembagian laba untuk berinvestasi pada hal lebih menguntungkan seperti ekspansi perusahaan, kebutuhan dana untuk operasional perusahaan, mempertahankan likuiditas perusahaan, pencapaian pada tujuan tertentu perusahaan yang berkaitan terhadap rasio pembayaran/ pendistribusian dividen dan faktor lain yang berhubungan dengan kebijakan dividen (Zuwita dan Enny, 2017).

Harahap (2018) menyatakan berbagai faktor yang menjadi pertimbangan perusahaan tentang kebijakan pendistribusian dividen kas kepada para pemegang saham atau investor pada suatu perusahaan. Diantara faktor tersebut adalah Cash Flow, Quick Ratio, Debt to Equity Ratio, Earning Per Share dan Return on Investment.

\subsection{Rumusan Masalah}

Rumusan masalah dalam penelitian ini dapat adalah bagaimanakah pengaruh Return on Investment, Quick Ratio, Current Ratio, Earning Per Share, Debt to Total Asset dan Firm Size secara parsial dan simultan terhadap pembagian dividen tunai perusahaan Indeks LQ45 yang terdaftar di Bursa Efek Indonesia?

\subsection{Tujuan Penelitian}

Penelitian ini bertujuan untuk menganalisis dan memperoleh bukti Berdasarkan latar belakang dan rumusan masalah yang telah di paparkan sebelumnya, adapun tujuan dari penelitian ini adalah untuk membuktikan secara empiris dan menganalisis dari pengaruh yang ada antara kepemilikan terkonsentrasi yang mana dalam penelitian ini adalah dengan menggunakan indikator kepemilikan terkonsentrasi dari pihak internal (insider) dan pihak eksternal (outsider) dan asimetri informasi terhadap penerapan konsep konservatisme akuntansi.

\section{KAJIAN PUSTAKA DAN PERUMUSAN HIPOTESIS}

\subsection{Analisis Rasio Keuangan}

Harahap (2018) mengemukakan bahwa "rasio keuangan adalah angka yang diperoleh dari hasil perbandingan dari satu post laporan keuangan dengan pos lainnya yang mempunyai hubungan yang relevan dan signifikan"

\subsection{Return on Investment}

Hanafi dan Halim (2018) mengemukakan Return On Investment merupakan kemampuan yang akan digunakan untuk menutup investasi yang dikeluarkan. Laba yang digunakan untuk mengukur rasio adalah laba bersih setelah pajak. Return On Investment membandingkan laba setelah pajak dengan total aktiva.

\subsection{Quick (acid test) Ratio}

Kasmir (2018) mengemukakan Quick Ratio merupakan kemampuan perusahaan dalam memenuhi kewajiban jangka pendeknya dengan menggunakan aktiva yang lebih likuid. Rasio ini hanya membandingkan antara aktiva yang sangat likuid terhadap kewajiban lancar. Apabila nilai Quick Ratio meningkat, maka semakin cepat perusahaan dapat melunasi semua hutang atau kewajibannya.

\subsection{Current Ratio}

Hanafi dan Abdul 2018 menjelaskan Current Ratio adalah salah satu ukuran dari rasio likuiditas yang diperoleh dengan membandingkan aktiva lancar 
terhadap kewajiban atau hutang lancar. Apabila Current Ratio meningkat, kemampuan perusahaan akan semakin cepat dalam melunasi hutang atau kewajiban jangka pendeknya. Current Ratio mempunyai nilai yang tinggi menggambarkan tingginya tingkat kepercayaan pemegang saham/ investor terhadap kemampuan perusahaan dalam mendistribusikan dividen yang telah dijanjikan perusahaan. Maka, terdapat pengaruh yang positif dan signifikan antara Current Ratio dengan pemberian dividen tunai.

\subsection{Debt to Total Asset}

Rasio ini digunakan untuk mengukur seberapa besar asset perusahaan dibiayai oleh hutang. Untuk keamanan pihak luar, rasio Debt to Total Assets dikatakan baik jika rasio ini rendah dan untuk pihak pemegang saham atau manajemen rasio Debt to Total Assets Ratio dikatakan baik jika rasio ini tinggi (Harahap, 2018)

\subsection{Earning Per Share}

Harahap (2018) mengemukakan bahwa "laba bersih per saham (Earning Per Share) adalah jumlah pendapatan yang diperoleh dalam satu periode untuk tiap lembar saham yang beredar, dan akan dipakai oleh pimpinan perusahaan untuk menentukan besarnya dividen yang akan dibagikan"

\subsection{Firm Size}

Ukuran perusahaan diukur dari logaritma natural nilai pasar ekuitas perusahaan pada akhir tahun, yaitu jumlah saham yang beredar pada akhir tahun dikalikan dengan harga pasar saham akhir tahun (Hanafi dan Abdul, 2018). Pertumbuhan suatu perusahaan akan mempengaruhi sejumlah kebijakan yang dibuat oleh perusahaan seperti kebijakan pendanaan, dividen, dan kompensasi.

\subsection{Model Penelitian}

Adapun model dalam penelitian ini adalah sebagai berikut:

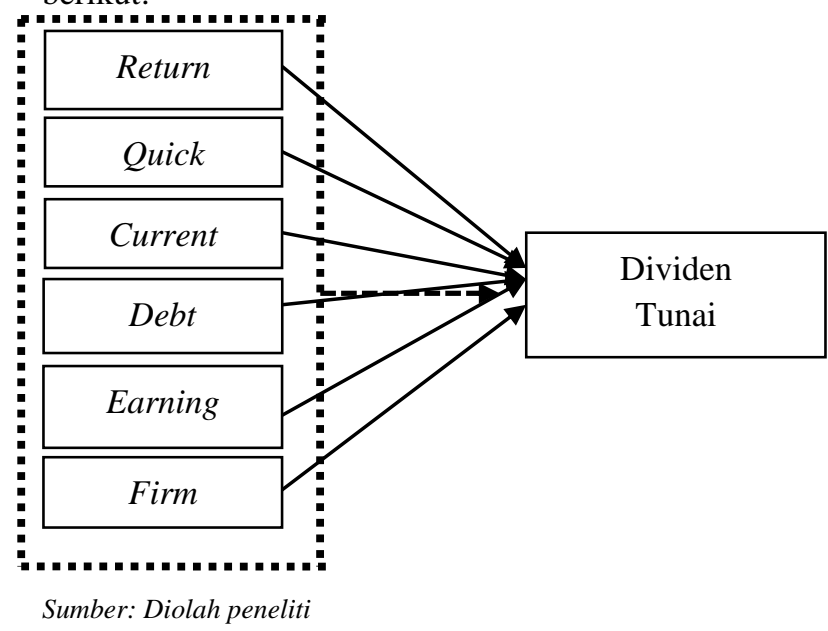

Sumber: Diolah peneliti

\section{Gambar 1. Model Penelitian}

Keterangan :

$\longrightarrow$ : Hubungan antar variabel secaraparsial

$\boldsymbol{\longrightarrow} \rightarrow$ : Hubungan variabel secara simultan

\subsection{Hipotesis}

$\mathrm{H}_{1}$. Return On Investment mempunyai pengaruh terhadap pembagian dividen tunai.

$\mathrm{H}_{2}$ Quick Ratio mempunyai pengaruh terhadap dividen tunai.

$\mathrm{H}_{3}$ Current Ratio mempunyai pengaruh terhadap dividen tunai.

$\mathrm{H}_{4}$ Debt to Total Asset mempunyai pengaruh terhadap dividen tunai.

$\mathrm{H}_{5} \quad$ Earning Per Share mempunyai pengaruh terhadap dividen tunai.

$\mathrm{H}_{6} \quad$ Firm Size mempunyai pengaruh terhadap dividen tunai.

$\mathrm{H}_{7}$ Return On Investment, Quick Ratio, Current Ratio, Debt to Total Asset, Earning Per Share dan Firm Size secara berama-sama mempunyai pengaruh terhadap dividen tunai.

\section{METODE PENELITIAN}

\subsection{Populasi dan Sampel}

Populasi dalam penelitian ini adalah perusahaan LQ45 yang terdaftar di Bursa Efek Indonesia (BEI) periode tahun 2015 sampai 2019.

Kriteria yang digunakan dalam penelitian ini berdasarkan penggunaan metode purposive sampling, dengan kriteria sebagai berikut:

1. Perusahaan yang selalu listing di Indeks LQ45 yang selama periode tahun 2015 sampai dengan 2019, artinya laporan keuangan haruslah selalu terdaftar di Perusahaan Indeks LQ45 pada Bursa Efek Indonesia selama lima Perusahaan Indeks LQ45 yang tidak memenuhi kriteria variabel Penelitian.

2. Perusahaan indeks LQ45 yang memiliki data yang lengkap berhubungan dengan variabel penelitian yakni Return On Investment, Quick Ratio, Current Ratio, Debt To Total Asset, Earning Per Share, Firm Size Dan Dividen Tunai.

3. Selama periode penelitian, perusahaan membagikan dividen. Alasannya bertujuan untuk memaksimalkan kemakmuran bagi para pemegang saham.

\subsection{Operasional Variabel}

Variabel yang digunakan dalam penelitian ini terdiri dari variabel bebas (independen) adalah Return On Investment, Quick Ratio, Current Ratio, Debt To Total Asset, Earning Per Share, Firm Size Dan Dividen Tunai, kemudian variabel dependen dalam penelitian ini adalah Dividen Kas. 


\begin{tabular}{|c|c|c|c|c|c|}
\hline No & Variabel & Definisi & Pengukuran & Jenis data & Skala \\
\hline 1. & $\begin{array}{l}\text { Return } \\
\text { (Hanafi, } \\
\text { 2018) }\end{array}$ & $\begin{array}{l}\text { Rasio yang } \\
\text { mengukur } \\
\text { kemampuan } \\
\text { perusahaan } \\
\text { secara } \\
\text { keseluruhan } \\
\text { didalam } \\
\text { menghasilkan } \\
\text { keuntungan } \\
\text { dengan jumlah } \\
\text { keseluruhan } \\
\text { aktiva yang } \\
\text { tersedia didalam } \\
\text { perusahaan }\end{array}$ & $\frac{\text { Laba Setelah Pajak }}{\text { Total Investasi }}$ & Sekunder & Rasio \\
\hline 2. & $\begin{array}{l}\text { Quick } \\
\text { Ratio } \\
\text { (Kasmir } \\
\text {,2016) }\end{array}$ & $\begin{array}{lr}\text { Rasio yang } \\
\text { mengukur } \\
\text { kemampuan } \\
\text { aktiva lancar } \\
\text { yang paling } \\
\text { likuid mampu } \\
\text { melunasi } & \text { hutang } \\
\text { lancar. }\end{array}$ & $\frac{\text { Aktiva lancar - persediaan }}{\text { Kewajiban Lancar }}$ & Sekunder & Rasio \\
\hline 3. & $\begin{array}{l}\text { Current } \\
\text { Ratio } \\
\text { (Munaw } \\
\mathrm{ir}, 2014 \text { ) }\end{array}$ & $\begin{array}{lr}\text { Rasio yang } \\
\text { dihitung dengan } \\
\text { membagi aktiva } \\
\text { lancar (current } \\
\text { assets) dengan } \\
\text { hutang atau } \\
\text { kewajiban lancar } \\
\text { (current liability) }\end{array}$ & $\frac{\text { Aktiva Lancar }}{\text { Kewajiban Lancar }}$ & Sekunder & Rasio \\
\hline 4. & $\begin{array}{l}\text { Debt to } \\
\text { Total } \\
\text { Asset } \\
\text { (Hery, } 2 \\
015 \text { ) }\end{array}$ & $\begin{array}{l}\text { Rasio yang } \\
\text { digunakan untuk } \\
\text { mengukur } \\
\text { perbandingan } \\
\text { antara total } \\
\text { hutang dan total } \\
\text { asset }\end{array}$ & $\frac{\text { Total Aktiva }}{\text { Total Kewajiban }}$ & Sekunder & Rasio \\
\hline 5. & $\begin{array}{l}\text { Earning } \\
\text { Per } \\
\text { Share } \\
\text { (Haraha } \\
\mathrm{p}, 2018 \text { ) }\end{array}$ & $\begin{array}{lr}\text { Rasio } & \text { yang } \\
\text { menggambarkan } \\
\text { jumlah rupiah } \\
\text { yang } & \text { diperoleh } \\
\text { untuk } & \text { setiap } \\
\text { lembar } & \text { saham } \\
\text { biasa } & \end{array}$ & $\frac{\text { Laba Setelah Pajak }}{\text { Jumlah Lembar Saham }}$ & Sekunder & Rasio \\
\hline 6. & $\begin{array}{l}\text { Firm } \\
\text { size } \\
\text { (Juming } \\
\text { an,2011 } \\
\text { ) }\end{array}$ & $\begin{array}{l}\text { Firm Size } \\
\text { (Ukuran } \\
\text { perusahaan) } \\
\text { Ukuran } \\
\text { perusahaan ini } \\
\text { diukur dengan } \\
\text { menghitung total } \\
\text { asset yang ada } \\
\text { pada masing- } \\
\text { masing } \\
\text { perusahaan }\end{array}$ & $\begin{array}{c}\text { Logaritma Natural } \\
\text { dari Total Asset }\end{array}$ & Sekunder & Rasio \\
\hline 7. & $\begin{array}{l}\text { Dividen } \\
\text { Kas } \\
\text { (Hanafi, } \\
2018 \text { ) }\end{array}$ & $\begin{array}{lr}\begin{array}{l}\text { Dividen } \\
\text { diberikan }\end{array} & \text { yang } \\
\text { perusahaan } & \text { oleh } \\
\text { kepada } & \text { para } \\
\text { pemegang } & \\
\text { sahamnya } & \text { dalam } \\
\text { bentuk } & \text { uang } \\
\text { tunai } & \end{array}$ & Total Dividen Kas & Sekunder & Rasio \\
\hline
\end{tabular}

Sumber: Penelitian Terdahulu

\subsection{Metode Analisis Data}

Penelitian melakukan pengujian dengan menggunakan analisis regresi linier berganda, yaitu metode statistik yang meneliti hubungan variabel terikat (dependen) dengan berbagai variabel terikat (independen). Model regresi yang akan dipakai untuk penelitian ini adalah sebagai berikut:

$$
Y=a+b_{1} X_{1}+b_{2} X_{2}+b_{3} X_{3}+b_{4} X_{4}+b_{5} X_{5}+b_{6} X_{6}+e
$$

\section{Keterangan:}

$Y \quad=$ Dividen Kas
$X_{1} \quad=$ Return On Investment

$X_{2} \quad=$ Quick Ratio

$X_{3} \quad=$ Current Ratio

$X_{4} \quad=$ Debt to Total Asset

$X_{5} \quad=$ Earning Per Share

$X_{6} \quad=$ Firm Size

$\mathrm{E} \quad=$ Error

$a \quad=$ Konstanta

$\mathrm{b}_{1}-\mathrm{b}_{3}=$ Koefesien Regresi

4. HASIL DAN PEMBAHASAN

\subsection{Statistik Deskriptif}

Tabel 2. Hasil Statistik Deskriptif

\begin{tabular}{|l|rr|c|cc|}
\hline Variabe1 & Max & Min & Mean & Std. Dev & N \\
Y & $2.600,00$ & 19,00 & 801,33 & 636,0963 & 75 \\
X1 & 0,4666 & 0,0113 & 0,1314 & 0,1099 & 75 \\
\hline X2 & 4,3206 & 0,2028 & 1,4768 & 0,9771 & 75 \\
\hline X3 & 4,8866 & 0,3114 & 1,9492 & 1,1501 & 75 \\
\hline X4 & 7,5153 & 1,3018 & 2,8942 & 1,6081 & 75 \\
X5 & $4.049,62$ & 26,84 & 684,1272 & 910,0835 & 75 \\
X6 & 19,6743 & 15,1737 & 17,4462 & 1,1713 & 75 \\
\hline
\end{tabular}

Sumber: Hasil pengolahan data dengan SPSS

Earning Per Share dari perusahaan selama periode pengamatan (2015-2019) dapat dilihat pada table diperoleh sebesar 684,1272 dengan nilai standar deviasi adalah 910,0835. Nilai standar deviasi dari Earning Per Share lebih besar dari standar deviasi rata-rata, hal ini menunjukkan data Earning Per Share bervariasi atau heterogen. Sementara variabel yang lain yaitu Return On Investment, Quick Ratio, Current Ratio, Debt to Total Asset dan Firm Size memiliki hasil perhitungan standar deviasi yang lebih kecil dari rata-rata yang berarti data dari keempat variabel tersebut homogen.

\subsection{Uji Asumsi Klasik}

\subsubsection{Uji Normalitas}

Uji ini memiliki tujuan menguji setiap variabel didalam model regresi berdistribusi normal atau tidak. Uji normalitas dilihat dengan menggunakan grafik normal P-P plot. Normalitas terjadi apabila penyebaran data(titik) yang terletak pada sumbu diagonal dari grafik normal.

Hasil uji normalitas dapat dilihat dari grafik pada gambar berikut ini :

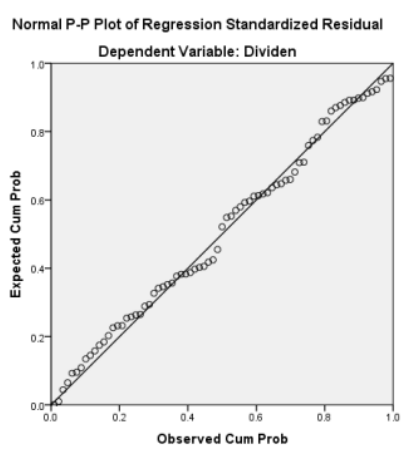

Sumber:Hasil pengolahan data dengan SPSS

Gambar 2. Hasil Uji Normalitas Data 
Apabila dilihat dari Grafik 2, data menyebar disekitaran garis grafik histogram lalu mengikuti arah garis diagonal atau garis grafik histogramnya menunjukan pola distribusi normal, maka dapat disimpulkan bahwa model regresi memenuhi asumsi

\subsubsection{Uji Multikolinearitas}

Tabel 3. Hasil Uji Multikolinearitas

\begin{tabular}{|c|c|c|c|}
\hline \multirow[b]{2}{*}{ Variabel } & \multicolumn{2}{|c|}{ Coliniearity Statistics } & \multirow{2}{*}{ Kesimpulan } \\
\hline & $\begin{array}{c}\text { Tolerance } \\
\text { Value }\end{array}$ & VIF & \\
\hline $\mathrm{X} 1$ & 0.568 & 1.761 & $\begin{array}{c}\text { Tidak terjadi } \\
\text { multikolinieritas }\end{array}$ \\
\hline $\mathrm{X} 2$ & 0.121 & 8.253 & $\begin{array}{c}\text { Tidak terjadi } \\
\text { multikolinieritas }\end{array}$ \\
\hline $\mathrm{X} 3$ & 0.108 & 9.291 & $\begin{array}{c}\text { Tidak terjadi } \\
\text { multikolinieritas }\end{array}$ \\
\hline $\mathrm{X} 4$ & 0.168 & 5.966 & $\begin{array}{c}\text { Tidak terjadi } \\
\text { multikolinieritas }\end{array}$ \\
\hline $\mathrm{X} 5$ & 0.597 & 1.675 & $\begin{array}{c}\text { Tidak terjadi } \\
\text { multikolinieritas }\end{array}$ \\
\hline X6 & 0.513 & 1.948 & $\begin{array}{c}\text { Tidak terjadi } \\
\text { multikolinieritas }\end{array}$ \\
\hline
\end{tabular}

Sumber: Hasil pengolahan data dengan SPSS

Hasil uji multikolinieritas menunjukan bahwa semua variable penelitian memiliki nilai VIF (variance inflation factor) di atas lebih kecil dari 10, dimana nilai terendah 1,025 dan tertinggi 7,409 lebih kecil dari 10 $(<10)$ batas nilai toleransi yang ditentukan dalam penelitian ini, artinya bilai nilai VIF lebih kecil 10 dari batas nilai toleransi yang ditentukan adalah tidak terjadi multikolinieritas atau tidak terjadi hubungan antara setiap variable yang ada dalam model penelitian.

\subsubsection{Uji Heterokedastisitas}

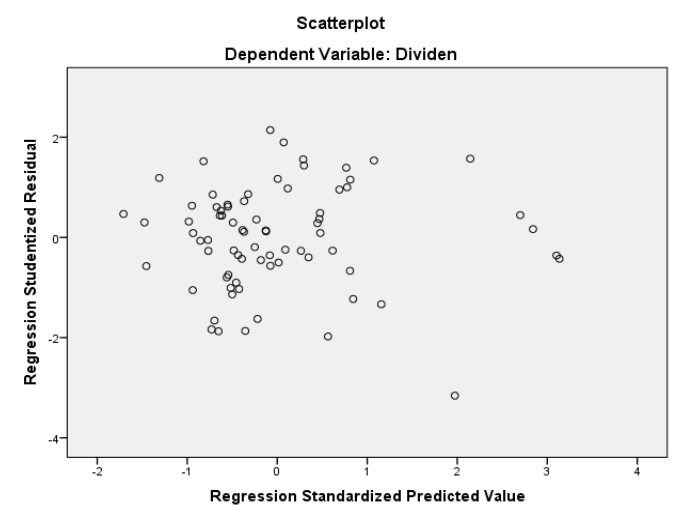

Sumber: Hasil pengolahan data dengan SPSS

\section{Gambar 3. Grafik Scatterplot}

Grafik scatterplot menunjukkan tidak terjadi heterokedastisitas. Hal ini berdasarkan grafik dimana titik-titik yang ada didalam grafik tidak membentuk pola tertentu yang jelas dan titik-titik tersebut tersebar diatas dan dibawah angka 0 pada sumbu Y.

\subsubsection{Uji Autokorelasi}

Tabel 4. Hasil Uji Autokorelasi Data dengan Durbin-Watson

\begin{tabular}{|l|c|c|r|r|r|}
\hline Mod & $\mathrm{R}$ & $\mathrm{R}$ & \multicolumn{1}{|c|}{ Adjusted R } & Std. Error of & Durbin- \\
$\mathrm{el}$ & & Square & \multicolumn{1}{c|}{ Square } & the Estimate & Watson \\
\hline 1 & $.886^{\mathrm{a}}$ & .785 & .766 & .59043 & 1.769 \\
\hline
\end{tabular}

a. Predictors: (Constant), Return, Quick, Current, Debt, Earning, Firm

b. Dependent Variable: Dividen

Sumber: Hasil pengolahan data dengan SPSS

Nilai Durbin Watson dapat dilihat dari Tabel 4 di atas, Durbin Watson $(\mathrm{D}-\mathrm{W})=2.229$, sehingga dapat disimpulkan bahwa tidak ada autokorelasi dengan ditunjukkan $1<1.769$ (nilai DW) $<3$.

\subsection{Uji Regresi Berganda}

Analisis ini digunakan untuk mengukur kekuatan dua variabel atau lebih dan juga menunjukkan arah hubungan antar variabel dependen dengan variabel independen. Perhitungan analisis regresi dapat dilihat pada tabel 5 berikut ini:

Tabel 5. Hasil Analisis Regresi Linear Berganda

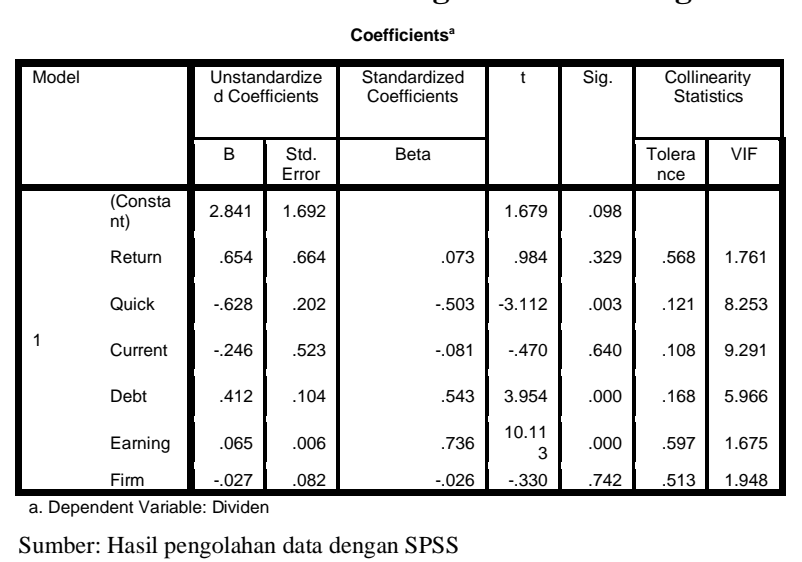

Dari tabel di atas dapat disusun persamaan regresi linier berganda sebagai berikut:

$$
\begin{aligned}
\text { Dividen Kas }= & 2,841+0,654 \text { Return }-0,628 \text { Quick } \\
& -0,246 \text { Current }+ \text { 0,412 Debt }+ \\
& \text { 0,065 Earning - 0,027 Firm }
\end{aligned}
$$

Persamaan linier berganda tersebut dapat diinterpretasikan sebagai berikut:

1. Nilai konstanta $(\alpha)$ sebesar 2,841 menunjukkan bahwa selama periode pengamatan, rata-rata dividen kas sebesar Rp. 2,841. Dalam hal ini apabila semua variabel independen sama dengan 0 (nol).

2. Koefisien regresi untuk Return On Investment ( $\beta 1)$ sebesar 0,654 artinya setiap perubahan satu satuan rasio keuangan Return On Investment, maka dividen kas akan mengalami kenaikan sebesar 0,654 satuan. Dalam hal ini faktor lain yang mempengaruhi dividen kas dianggap tetap. 
3. Koefisien regresi untuk Quick Ratio $(\beta 2)$ sebesar 0,628 artinya setiap perubahan satu satuan rasio keuangan Quick Ratio, maka dividen kas akan mengalami penurunan 0,628 satuan. Dalam hal ini faktor lain yang mempengaruhi dividen kas dianggap tetap.

4. Koefisien regresi untuk Current Ratio ( $\beta 2)$ sebesar $-0,246$ artinya setiap perubahan satu satuan rasio keuangan Current Ratio, maka dividen kas akan mengalami penurunan 0,246 satuan. Dalam hal ini faktor lain yang mempengaruhi dividen kas dianggap tetap.

5. Koefisien regresi untuk Debt to Total Asset sebesar 0,412 artinya setiap perubahan satu satuan rasio keuangan Debt to Total Asset, maka dividen kas akan mengalami kenaikan 0,412 satuan. Dalam hal ini faktor lain yang mempengaruhi dividen kas dianggap tetap.

6. Koefisien regresi untuk Earning Per Share ( $\beta 3)$ 0,065 artinya setiap perubahan satu satuan rasio keuangan Earning Per Share, maka dividen kas akan mengalami kenaikan sebesar 0,065 satuan. Dalam hal ini faktor lain yang mempengaruhi dividen kas dianggap tetap.

7. Koefisien regresi untuk Firm Size $(\beta 4)$ sebesar 0,027 artinya setiap perubahan satu satuan rasio keuangan Firm Size, maka dividen kas akan mengalami penurunan sebesar 0,027 satuan.

\subsection{Pengujian Hipotesis}

\subsubsection{Uji Parsial (Uji t)} bahwa:

Hasil uji parsial (uji t) pada Tabel 5 menunjukkan

1. Pengaruh Return On Investment terhadap Dividen Tunai dapat dilihat dengan memperhatikan nilai probabilitas signifikan dapat dilihat pada tabel 5 sebesar 0,098. Karena 0,098> 0,05 atau 5\%(derajat kepercayaan), kesimpulannya Return On Investment secara signifikan tidak berpengaruh terhadap dividen kas.

2. Pengaruh Quick Ratio terhadap Dividen Tunai dapat dilihat dengan memperhatikan nilai probabilitas signifikan dapat dilihat pada tabel 5 sebesar 0,032<0,05 atau 5\%(derajat kepercayaan), kesimpulannya Quick Ratio secara signifikan berpengaruh terhadap dividen kas.

3. Pengaruh Current Ratio terhadap Dividen Tunai dapat dilihat dengan memperhatikan nilai probabilitas signifikan dapat dilihat pada tabel 5 sebesar 0,640>0,05 atau 5\%(derajat kepercayaan), kesimpulannya Current Ratio secara signifikan tidak berpengaruh terhadap dividen kas.

4. Pengaruh Debt to Total Asset terhadap Dividen Tunai dapat dilihat dengan memperhatikan nilai probabilitas signifikan dapat dilihat pada tabel 5 sebesar $0,000<0,05$ atau 5\%(derajat kepercayaan), kesimpulannya Debt to Total Asset secara signifikan tidak berpengaruh terhadap dividen kas.

5. Pengaruh Earning Per Share terhadap Dividen Tunai dapat dilihat dengan memperhatikan nilai probabilitas signifikan dapat dilihat pada tabel 5 sebesar $0,000<0,05$ atau 5\%(derajat kepercayaan), kesimpulannya Earning Per Share secara signifikan tidak berpengaruh terhadap dividen kas.

6. Pengaruh Firm Size terhadap Dividen Tunai dapat dilihat dengan memperhatikan nilai probabilitas signifikan dapat dilihat pada tabel 5 sebesar 0,742> 0,05 atau 5\%(derajat kepercayaan), kesimpulannya Firm Size secara signifikan tidak berpengaruh terhadap dividen kas.

\subsubsection{Uji Simultan (Uji F)}

Tabel 6. Hasil Uji Simultan (Uji F)

\begin{tabular}{|c|c|c|c|c|c|c|}
\hline \multicolumn{7}{|c|}{ ANOVA $^{a}$} \\
\hline \multicolumn{2}{|c|}{ Model } & Sum of & df & Mean & $\mathrm{F}$ & Sig. \\
\hline \multirow{3}{*}{1} & Regression & 86.442 & 6 & 14.407 & 41.327 & $.000^{\mathrm{b}}$ \\
\hline & Residual & 23.705 & 68 & .349 & & \\
\hline & Total & 110.147 & 74 & & & \\
\hline
\end{tabular}

a. Dependent Variable: Dividen

b. Predictors: (Constant), Firm, Earning, Debt, Return, Quick, Current

Sumber: Hasil pengolahan data dengan SPSS

Tabel di atas diketahui bahwa nilai probabilitas (probabilitas value) yang diukur pada penelitian tersebut yaitu sebesar 0,000>0,05 atau 5\%(derajat kepercayaan) sehingga hipotesis diterima. Kesimpulannya yaitu Return On Investment, Quick Ratio, Current Ratio, Debt to Total Asset, Earning Per Share dan Firm Size berpengaruh secara simultan terhadap Dividen Tunai.

\subsubsection{Uji Koefisien Determinasi}

Tabel 7. Hasil Uji Koefisien Determinasi

\begin{tabular}{|c|c|c|c|c|}
\hline \multicolumn{5}{|c|}{ Model Summary } \\
\hline Model & $\mathrm{R}$ & R Square & $\begin{array}{l}\text { Adjusted R } \\
\text { Square }\end{array}$ & $\begin{array}{c}\text { Std. Error of the } \\
\text { Estimate }\end{array}$ \\
\hline 1 & $.886^{a}$ & .785 & .766 & .59043 \\
\hline
\end{tabular}

a. Predictors: (Constant), Firm, Earning, Debt, Return, Quick, Current

b. Dependent Variabel: Dividen

Sumber: Hasil pengolahan data dengan SPSS

Koefisien determinasi (R2) mempunyai nilai 0,785. Hal ini membuktikan besarnya pengaruh variabel bebas (independen) yakni Return On Investment, Quick Ratio, Earning Per Share dan Firm Size terhadap variabel bebas (dependen) yakni Dividen Kas, bisa dijelaskan dalam model persamaan tersebut adalah sebesar $79 \%$ lalu sisanya $21 \%$ telah dipengaruhi oleh faktor-faktor lainnya yang tidak termasuk dalam model regresi.

\subsection{Pembahasan}

1. Pada hipotesis yang pertama (H1) yang menyatakan bahwa "Return On Investment memiliki pengaruh terhadap dividen kas"adalah 
tidak terbukti. Hasilnya diterangkan dengan besarnya Sig.t (nilai signifikansi t) adalah sebesar $0,098>0,05$ atau $5 \%$ (derajat kepercayaan). Sehingga dapat dikatakan tidak adanya pengaruh yang signifikan dari variabel Return On Investment terhadap dividen kas. Dari hasil analisis dapat diketahui bahwa laba ternyata tidak digunakan untuk pembayaran dividen.

2. Pada hipotesis yang kedua (H2) yang menyatakan bahwa "Quick Ratio memiliki pengaruh terhadap dividen kas"adalah terbukti. Hasilnya diterangkan dengan besarnya Sig.t (nilai signifikansi t) adalah sebesar $0,003<0,05$ atau $5 \%$ (derajat kepercayaan). Sehingga dapat dikatakan tidak adanya pengaruh yang signifikan dari variabel Quick Ratio terhadap dividen kas. Hasil ini mengindikasikan bahwa Quick Ratio sangat diperhatikan manajemen perusahaan dalam mempertimbangkan keputusan untuk membayarkan besarnya dividen kas yang akan diberikan.

3. Pada hipotesis yang ketiga (H3) yang menunjukkan "Current Ratio memiliki pengaruh terhadap dividen kas"adalah tidak terbukti. Hasilnya diterangkan dengan besarnya Sig.t (nilai signifikansi t) adalah sebesar 0,640>0,05 atau 5\%(derajat kepercayaan). Sehingga dapat dikatakan bahwa variabel Current Ratio tidak berpengaruh signifikan terhadap dividen kas. Tidak signifikan disini menunjukkan bahwa Current Ratio tidak terlalu terhadap dividen kas. Perusahaan menggunakan laba yang diperoleh untuk menjaga likuiditas perusahaan.

4. Pada hipotesis yang keempat (H4) yang menyatakan bahwa "Debt to Total Asset memiliki pengaruh terhadap dividen kas"adalah terbukti. Hasilnya diterangkan dengan besarnya Sig.t (nilai signifikansi t) adalah sebesar $0,000<0,05$ atau 5\%(derajat kepercayaan). Sehingga dapat dikatakan bahwa variabel Debt to Total Asset mempunyai pengaruh yang signifikan terhadap dividen kas. Hasil ini mengindikasikan bahwa Debt to Total Asset sangat diperhatikan manajemen perusahaan dalam mempertimbangkan keputusan untuk membayarkan besarnya dividen kas yang akan diberikan.

5. Pada hipotesis yang kelima (H5) yang menunjukkan"Earning Per Share memiliki pengaruh terhadap dividen kas"adalah terbukti. Hasilnya diterangkan dengan besarnya Sig.t (nilai signifikansi t) adalah sebesar $0,000<0,05$ atau 5\%(derajat kepercayaan). Sehingga dapat dikatakan bahwa variabel Earning Per Share mempunyai pengaruh yang signifikan terhadap dividen kas. Hasil ini mengindikasikan bahwa Earning Per Share sangat diperhatikan manajemen perusahaan dalam mempertimbangkan keputusan untuk membayarkan besarnya dividen kas yang akan diberikan.

6. Hipotesis yang keenam (H6) menunjukkan bahwa "Firm Size memiliki pengaruh terhadap dividen kas"adalah tidak terbukti. Hasilnya diterangkan dengan besarnya Sig.t (nilai signifikansi t) adalah sebesar 0,742>0,05 atau 5\%(derajat kepercayaan). Sehingga dapat dikatakan bahwa variabel Firm Size tidak mempunyai pengaruh yang signifikan terhadap dividen kas. Hal ini disebabkan oleh keputusan manajemen perusahaan untuk mengalihkan dana untuk menginvestasikan kembali, ekspansi perusahaan dan kegiatan yang menggunakan pendanaan selain pendistribusian dividen kas.

\section{SIMPULAN DAN SARAN}

\subsection{Simpulan}

1. Return On Investment tidak mempunyai pengaruh terhadap dividen kas Dari hasil analisis dapat diketahui bahwa laba ternyata tidak digunakan untuk pembayaran dividen. Laba bersih perusahaan diinvestasikan kembali dalam aset yang produktif.

2. Quick Ratio berpengaruh terhadap dividen kas. Dengan demikian, Quick Ratio dapat dijadikan pertimbangan berinvestasi dalam mengharapkan dividen tunai.

3. Current Ratio tidak berpengaruh terhadap dividen kas. Manajemen perusahaan juga ingin mempertahankan tingkat likuiditas untuk memberikan perlindungan dan fleksibilitas keuangan terhadap ketidakpastian.

4. Debt to Total Asset berpengaruh terhadap dividen kas. Dengan demikian, Debt to Total Asset dapat dijadikan pertimbangan berinvestasi dalam mengharapkan dividen tunai.

5. Earning Per Share berpengaruh terhadap dividen kas. Dengan demikian, Debt to Total Asset dapat dijadikan pertimbangan berinvestasi dalam mengharapkan dividen tunai.

6. Firm Size tidak berpengaruh terhadap dividen kas. Hal ini disebabkan oleh keputusan manajemen perusahaan untuk mengalihkan dana untuk menginvestasikan kembali, ekspansi perusahaan dan kegiatan yang menggunakan pendanaan selain pendistribusian dividen kas.

7. Return On Investment, Quick Ratio, Current Ratio, Debt to Total Asset,Earning Per Share dan Firm Size bersama-sama mempunyai pengaruh terhadap dividen kas.

\subsection{Saran}

1. Bagi peneliti selanjutnya penelitian ini lebih baik menggunakan sampel dari penelitian yang memiliki area yang lebih luas/banyak lagi yakni dengan menambahkan tahun penelitian yang lebih lama dari penelitian ini serta memasukkan objek pada penelitian yang lebih luas dari area ini seperti membandingkan terhadap indeks KOMPAS100, Indeks27, Jakarta IslamicIndex. Sehingga data tersebut mempunyai area cakupan yang lebih luas guna dijadikan sampel untuk penelitian selanjutnya. Peneliti selanjutnya juga lebih baik 
menggunakan seluruh perusahaan yang terdaftar di Bursa Efek Indonesia sebagai sampel penelitian.

2. Bagi Investor akan sangat baik untuk mempertimbangkan berbagai hal yang sangat penting dalam melakukan pengambilan keputusan investasi yang akan dilakukannya, sehingga hal ini akan memberikan profit yang baik baginya..

3. Bagi pihak perusahaan untuk perusahaan Indeks LQ45 penelitian ini diharapkan akan dapat menjadi dasar dalam memutuskan keputusan perusahaan sehubungan terhadap pembayaran dividen kas kepada pemangku saham (investor).

\section{DAFTAR REFERENSI}

Amyas, Muhammad Arfan dan Hasan Basri. 2014. "Pengaruh Quick Ratio, earning per share, dan return on investment terhadap dividen kas". Jurnal Akuntansi ISSN 2302-0164. Magister Akuntansi Pascasarjana Universitas Syiah Kuala Banda Aceh. Pp. 1- 9.

Baridwan, Zaki. 2009. Intermediate Accounting. BFFE: Yogyakarta

Bidari, Wiwin Leony, Putu Kepramareni dan Ni Luh Gde Novitasari. 2018. "Pengaruh Laba Akuntansi, Earning Per Share dan Laba Tunai Terhadap Dividen Kas (Studi pada perusahaan manufaktur yang terdaftar di Bursa Efek Indonesia)". Jurnal Riset Akuntansi. Volume 8 No.1. Hal.75-85

Dewi, Dian Masita. 2016. "Pengaruh Likuiditas, Leverage, Ukuran Perusahaan Terhadap Kebijakan Dividen Tunai Dengan Profitabilitas Sebagai Variabel Intervening". Jurnal Bisnis dan Ekonomi, Hal. 12 - 19 Vol. 23, No. 1.

Fahmi, Irham. 2018. Analisis Laporan Keuangan. Bandung: Alfabeta

Ghozali, Imam. 2016. Aplikasi Analisis Multivariate dengan Program IBM SPSS 23. Semarang: Badan Penerbit Universitas Diponegoro.

Gloria Julianita Sendow, Grace B. Nangoi, Winston Pontoh. 2018. "Faktor - Faktor Yang Mempengaruhi Kebijakan Dividen Pada Perusahaan Manufaktur Yang Terdaftar Di Bursa Efek Indonesia Periode Tahun 2012-2016". Program Magister Akuntansi, Fakultas Ekonomi dan Bisnis Universitas Sam Ratulangi.

Hanafi, Mamduh M. dan Abdul Halim. 2018. Analisis Laporan Keuangan Edisi Kelima. Yogyakarta: UPP STIM YKPN.

Harahap, Sofjan Syafri. 2018. Analisis Kritis atas Laporan Keuangan. Jakarta: PT. Raja Grafindo Persada.

Hery. 2015. Analisis Laporan Keuangan. Jakarta: Bumi Aksara.

Husein, Umar. 2017. Metode Penelitian untuk Skripsi dan Tesis Bisnis. Jakarta : Raja-wali Pers.

Ifada, Luluk Muhimatul dan Nia Kusuma Dewi. 2014. "Pengaruh laba bersih, arus kas operasional, investment opportubity set dan firm size terhadap dividen kas". Jurnal Dinamika Akuntansi. Vol. 6 No. 2 September 2014. Pp. 177-190.

Irman, Mimelientesa, Gilang Satria Guinata dan Haugesti Diana. 2020. "Pengaruh Laba Bersih, Arus Kas Operasi dan Current Ratio terhadap Dividen Kas pada Perusahaan Aneka Industri yang terdaftar di Bursa Efek Indonesia". Jurnal Akuntansi, kewirausahaan dan Bisnis. Vol. 5 No. 1. Hal. 24-36.

Jumingan. 2011. Analisis Laporan Keuangan. Jakarta : Bumi Aksara

Kasmir. 2018. Analisis Laporan Keuangan. Bandung: Rajawali Pers.

Kieso, Donald E. Weygandt Jerry J. dan Terry D. Warfield. 2018. Akuntansi Intermediate. Edisi IFRS. Volume 2. Alih Bahasa: Emil Salim. Jakarta : Erlangga.

Muljono, D. 2015. Akuntansi dan Lembaga Keuangan Syariah. Yogyakarta: ANDI.

Munawir, S. 2014. Analisis Laporan Keuangan. Yogyakarta : Liberty.

Mutya, Anisa dan Vaya Juliana Dillak. 2018. "Analisis Faktor-Faktor yang Mempengaruhi Dividen Kas". Jurnal Aksara Public. Volume 2. No. 4 Hal 63-74.

Puspitawati, Lilis, Herlas Tia Dekayani 2014. "Pengaruh Laba Bersih dan Current Ratio Terhadap Dividen Kas Pada Perusahaan Pertambangan Yang Terdaftar di Bursa Efek Indonesia". Jurnal riset akuntansi, Universitas Komputer Indonesia.

Rahayu, Alia Sugeng , Mohammad Hari. 2016. "Pengaruh Current Ratio dan Quick Ratio terhadap Kebijakan Dividen Melalui Return On Equity Pada Perusahaan Manufaktur yang Terdaftar di BEI Tahun 2014". Jurnal Ekonomi Bisnis, Nomor 2. Fakultas Ekonomi Universitas Negeri Malang.

Ratnasari, Putu Sri Puspytha dan Ni Ketut Purnawati. 2019. "Pengaruh Profitabilitas, Likuiditas, Tingkat Pertumbuhan Perusahaan dan Leverage terhadap Kebijakan Dividen". E-Jurnal Ekonomi dan Bisnis. Vol. 8, No. 10, 2019. Hal : 6179-6198.

Sekaran, Uma dan Roger Bougie. 2017. Metode Penelitian untuk Bisnis : Pendekatan Pengembangan - Keahlian. Edisi 6. Buku 2. Jakarta Selatan : Salemba Empat.

Siregar, Cici Seliana. 2019. "Analisis Pengaruh Laba Akuntansi, Laba Tunai dan Likuiditas terhadap Dividen Kas Pada Perusahaan Manufaktur yang terdaftar di Bursa Efek Indonesia". Journal Economy and Currency Study. Volume 1 Issue 2. 
Hal.27-34.

Stice, James D., Earl K. Stice, Fred Skousen. 2011. Intermediate Accounting. 17th Edition. USA. Cengage Learning.

Subramanyam, K. R. dan John J. Wild. 2013. Analisa Laporan Keuangan. Jakarta : Salemba Empat.

Wicaksono, Ramadhanu Adi ,Widya Susanti dan Mahsina. 2016. "Analisis pengaruh Cash Position, Debt to Total Asset dan Return On Asset terhadap Cash Dividend pada perusahaan LQ45 yang go public di Bursa Efek Indonesia". Jurnal Akuntansi UBHARA.Vol 3. Hal.110-120

Zuwita, Ega dan Deliza Enny. 2017. "Analisis pengaruh Likuiditas, Profitabilitas, Leverage, Arus Kas Bebas dan Dividen tahun sebelumnya terhadap Dividen Kas". Jurnal Akuntansi Trisakti. Vol.4 No.2. Hal.101-116. 